U.S. Geological Survey Information Relevant to the U.S. Geological Survey Assessment of the Middle Devonian Marcellus Shale of the Appalachian Basin Province, 2011

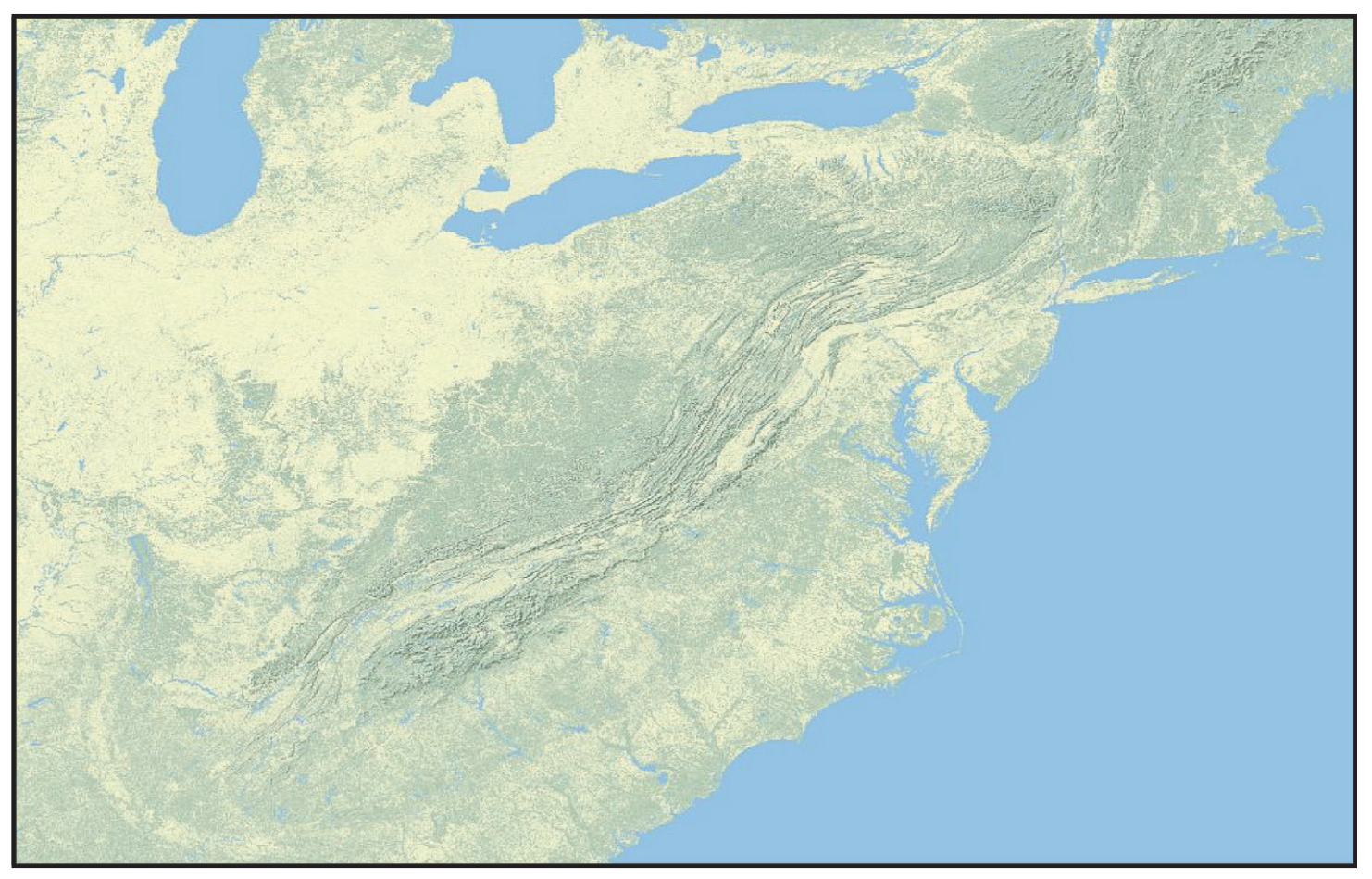

Open-File Report 2011-1298

U.S. Department of the Interior

U.S. Geological Survey 


\section{U.S. Geological Survey Information Relevant to the U.S. Geological Survey Assessment of the Middle Devonian Marcellus Shale of the Appalachian Basin Province, 2011}

USGS Marcellus Shale Assessment Team

Open-File Report 2011-1298

U.S. Department of the Interior

U.S. Geological Survey 


\section{U.S. Department of the Interior \\ KEN SALAZAR, Secretary}

\section{U.S. Geological Survey \\ Marcia K. McNutt, Director}

U.S. Geological Survey, Reston, Virginia: 2011

For product and ordering information:

World Wide Web: http://www.usgs.gov/pubprod

Telephone: 1-888-ASK-USGS

For more information on the USGS—-the Federal source for science about the Earth,

its natural and living resources, natural hazards, and the environment:

World Wide Web: http://www.usgs.gov

Telephone: 1-888-ASK-USGS

Suggested citation:

USGS Marcellus Shale Assessment Team, 2011, Information relevant to the U.S. Geological Survey assessment of the Middle Devonian Shale of the Appalachian Basin Province, 2011: U.S. Geological Survey Open-File Report 2011-1298, 22 p.

Any use of trade, product, or firm names is for descriptive purposes only and does not imply endorsement by the U.S. Government.

Although this report is in the public domain, permission must be secured from the individual copyright owners to reproduce any copyrighted material contained within this report. 


\section{Contents}

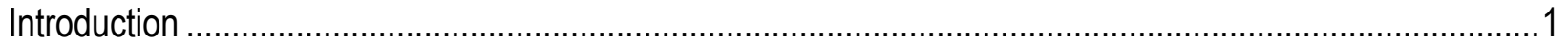

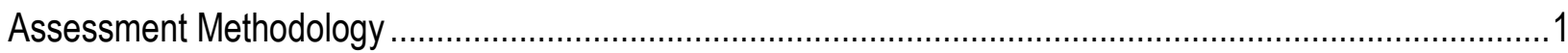

Marcellus Shale Isopach Map .............................................................................................

Marcellus Shale Assessment Units ..........................................................................................

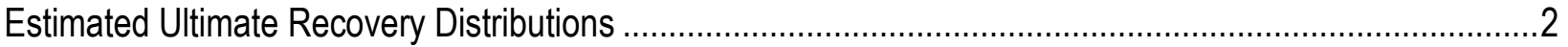

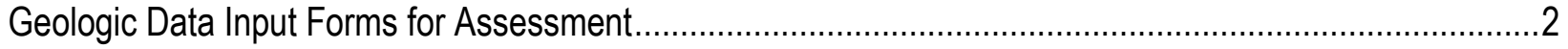

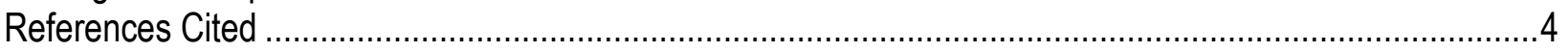

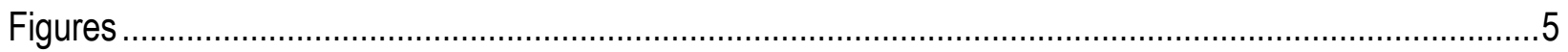

Appendix 1. Geologic input data for the assessment of the Foldbelt Marcellus Assessment Unit

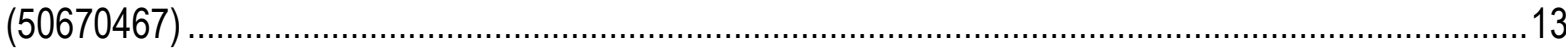

Appendix 2. Geologic input data for the assessment of the Interior Marcellus Assessment Unit

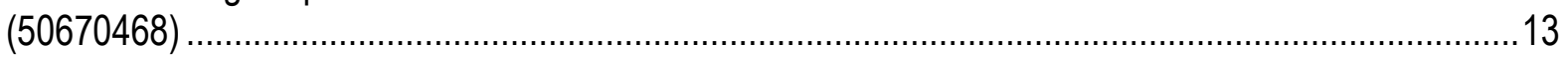

Appendix 3. Geologic input data for the assessment of the Western Margin Marcellus Assessment

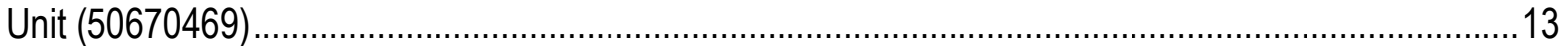

\section{Figures}

1. Location map showing the boundary of the Appalachian Basin Province (red line) as defined for USGS assessments.

2. Generalized stratigraphic nomenclature representing late Mississippian and Devonian rocks of the northern part of the Appalachian Basin Province. The Marcellus Shale is Middle Devonian in age. Modified from Milici and Swezey (2006)

3. Generalized 50-foot isopach maps of the Marcellus Shale in the Appalachian Basin Province. The shaded area represents the area in which the thickness of the Marcellus Shale is greater than or equal to 50 feet; the unshaded area within the black line represents that area in which the Marcellus Shale is less than 50 feet thick. These isopach lines were used directly in the definition of assessment unit boundaries.

4. Map showing the boundaries of the three assessment units (AU) of the Marcellus Shale assessed by the USGS.

5. Map showing the boundary of the Foldbelt Marcellus Assessment Unit (AU) in the Appalachian Basin Province.

6. Map showing the boundary of the Interior Marcellus Assessment Unit (AU) in the Appalachian Basin Province.

7. Map showing the boundary of the Western Margin Marcellus Assessment Unit (AU) in the Appalachian Basin Province.

8. Distributions of Estimated Ultimate Recovery (EUR) for 26 shale gas assessment units assessed by the USGS. Each distribution is a truncated shifted lognormal and represents a smooth curve. Black diamonds represent the mean for each distribution. This family of distributions was used as potential EUR analogs for the three Marcellus Shale assessment units 


\title{
Information Relevant to the U.S. Geological Survey Assessment of the Middle Devonian Marcellus Shale of the Appalachian Basin Province, 2011
}

\author{
USGS Marcellus Shale Assessment Team
}

\section{Introduction}

The U.S. Geological Survey (USGS) recently assessed the potential for natural gas resources in the Middle Devonian Marcellus Shale of the Appalachian Basin Province (Coleman and others, 2011). The Marcellus Shale was assessed as a continuous gas accumulation using a methodology identical to that used in the assessment of shale and other continuous-type assessment units throughout the United States. This preliminary report provides some additional geologic information used in the Marcellus Shale assessment.

The Appalachian Basin Province encompasses rocks of the Paleozoic passive margins, the foreland basins, and fold and thrust belts formed during several episodes in the Paleozoic (fig. 1). The Marcellus Shale is one of many marine shales deposited in the area that is now encompassed by the Appalachian Basin Province. The stratigraphy of Devonian shales and other rocks in the northern part of the Appalachian Basin is shown in figure 2.

\section{Assessment Methodology}

Since the Energy Policy and Conservation Act Amendments legislation was signed in 2000, the USGS has been required by law to assess priority provinces of the United States using the same assessment methodology. The USGS uses two peerreviewed methodologies, one for conventional resources and one for continuous resources (shale gas, shale oil, tight gas, and coalbed gas). The methodology for the assessment of continuous accumulations such as the Marcellus Shale was summarized in several reports (Crovelli, 2002; Klett and Schmoker, 2002; Schmoker, 2002; Klett and Charpentier, 2003).

In each assessment, the geologists responsible for leading the assessment are required to complete a data-input form that integrates all of the geologic and engineering knowledge that is required for a quantitative assessment. The input forms for the Marcellus Shale assessment are provided in this report (Appendix 1-3); detailed explanations of the assessment input await a more formal USGS peer-reviewed publication. 


\section{Marcellus Shale Isopach Map}

In this assessment, the definition of assessment units in the Marcellus Shale was based on several mapped geologic parameters, including a generalized isopach map of the Marcellus Shale (fig. 3). The map in figure 3 represents the general differentiation of Marcellus Shale greater than or equal to 50 feet (ft) (shaded area), and Marcellus Shale thickness less than $50 \mathrm{ft}$ (within black line). These isopach boundaries were used in defining the boundaries of the assessment units in the Marcellus Shale (fig. 4). The general limit of the fold and thrust belt was also used in assessment-unit definition.

\section{Marcellus Shale Assessment Units}

The boundaries of the three Marcellus Shale assessment units reflect the thickness of the shale, thermal maturity of the shale, and the degree of structure represented by the extent of the fold and thrust belt. The Foldbelt Marcellus Assessment Unit (AU) is generally defined by the area with thickness of Marcellus Shale less than $50 \mathrm{ft}$ (fig. 5). The Interior Marcellus AU is generally defined by shale thickness greater than or equal to $50 \mathrm{ft}$ (fig. 6). The Western Margin Marcellus AU is defined by the general extent of the fold and thrust belt in the eastern part of the Appalachian Basin where the Marcellus Shale is present (fig. 7).

\section{Estimated Ultimate Recovery Distributions}

Cumulative Marcellus Shale production data were available from Pennsylvania and West Virginia for irregular time periods. These data were evaluated using a probabilistic analysis, but the quality of the data at the time of the assessment was considered not sufficient for the construction of individual well Estimated Ultimate Recovery (EUR) distributions. This probabilistic study was presented at the Petroleum Technology Transfer Council (PTTC) Conference held in Morgantown, W. Va., in March of 2011 (T. Cook, pers. comm., 2011).

Over the past ten years, the USGS has developed a series of EUR distributions for more than 20 shale-gas assessment units (fig. 8). This family of EUR distributions illustrates the total experience to date in the United States for estimated ultimate recoveries from shale-gas reservoirs. For each Marcellus AU being assessed, the geologist determines which distribution or set of distributions most nearly approximates the potential EUR distribution of the assessment units. This determination of the most appropriate EUR distribution was done along with the analysis of production data from Pennsylvania and West Virginia.

\section{Geologic Data Input Forms for Assessment}

The geologic data input forms that formed the basis of the assessment of three assessment units in the Marcellus Shale are provided in Appendixes 1-3. Some of the more critical input data are briefly described below.

Total assessment unit area (acres) (Line 1): the geologist defines the limits of the AU, using a mapped boundary, and the uncertainty of this mapped boundary is captured using a distribution for area. For example, the structures defining the limits of the Foldbelt Marcellus AU are well known, so the AU area ranged from a minimum of 
$11,590,000$ acres to a maximum of $12,810,000$ acres, with a mean of $12,200,000$ acres (Appendix 1).

Area per cell of untested cells (acres) (Line 2): this distribution captures the geologic variation in the drainage area of untested cells (non-interfering cells) within the assessment unit. For the Foldbelt Marcellus AU, the area per cell was guided by cell areas from analog shale-gas assessment units in the United States. Using analog data, the minimum cell size was found to be 80 acres. For all cells, there was a mode of 128 acres, a maximum of 240 acres, and a calculated mean of 149 acres (Appendix 1).

Untested area (percent) (Line 3): the geologist determines how much of the area of the AU is untested, given what is known of exploration within the AU. In this analysis, all wells are analyzed as to the tests conducted, which formations were tested, and if results represent an adequate test of the formation of interest. For the Foldbelt Marcellus $\mathrm{AU}$, the untested area is nearly 100 percent of the AU (Appendix 1).

Untested area having potential for undiscovered resources (percent) (Line 4): Using a distribution, the geologists have determined the amount of area in the AU that is untested and has potential to contain undiscovered oil or gas resources. This is largely a geologic determination and is based upon careful analyses of shale thickness, thermal maturity, organic content, analyses of tests within the formation of interest, and other considerations. For example, in the Interior Marcellus AU, the distribution of percent untested area of the $\mathrm{AU}$ that has potential for undiscovered resources ranges from 10 percent at the minimum and 25 percent at the median to 75 percent at the maximum, with a calculated mean of 37 percent. The mean of 37 percent represents the integration of all geologic characteristics as well as the application of the future success ratio to this $\mathrm{AU}$ (Appendix 2).

Total recovery per cell (BCFG): The geologists interpret a distribution for EUR. For example, in the Interior Marcellus AU, the EUR distribution was determined using production analogs from other assessed shale-gas reservoirs as a guide (fig. 8), following an analysis of the West Virginia and Pennsylvania data. The minimum EUR is 0.02 BCFG (standard for all gas assessments), the median EUR is 0.8 BCFG, and the maximum EUR is $12 \mathrm{BCFG}$, with a calculated mean of $1.15 \mathrm{BCFG}$. The mean of 1.15 $\mathrm{BCFG}$ places the Interior Marcellus AU in the uppermost part of the analog set for EUR in the United States.

Future Success Ratio (percent): a distribution characterizing future success ratio for wells potentially drilled in the Marcellus is determined from shale-gas analogs in the United States. For example, for the Interior Marcellus AU, the future success ratio is 76 percent at the minimum, 85 percent at the mode, 95 percent at the maximum, and a calculated mean future success ratio of 85 percent. 


\section{References Cited}

Coleman, J.L., Milici, R.C., Cook, T.A., Charpentier, R.R., Kirschbaum, M.A., Klett, T.R., Pollastro, R.M., and Schenk, C.J., 2011, Assessment of undiscovered oil and gas resources of the Devonian Marcellus Shale of the Appalachian Basin Province, 2011: U.S. Geological Survey Fact Sheet 2011-3092, 2 p. (Also available at http://pubs.usgs.gov/fs/2011/3092/.)

Crovelli, R.A., 2002, Analytical resource assessment method for continuous petroleum accumulations - The ACCESS assessment method, chap. 22 of Petroleum systems and geologic assessment of the southwestern Wyoming province, Wyoming, Colorado, and Utah: U.S. Geological Survey Digital Data Series DDS-69-D. (Also available at http://pubs.usgs.gov/dds/dds-069/dds-069-d/REPORTS/69_D_CH_22.pdf.)

Klett, T.R., and Schmoker, J.W., 2002, Input-data form and operational procedure for the assessment of continuous accumulations, 2002, chap. 18 of Petroleum systems and geologic assessment of the southwestern Wyoming province, Wyoming, Colorado, and Utah: U.S. Geological Survey Digital Data Series DDS-69-D. (Also available at http://pubs.usgs.gov/dds/dds-069/dds-069-d/REPORTS/69_D_CH_18.pdf.)

Klett, T.R., and Charpentier, R.R., 2003, FORSPAN Model users guide: U.S. Geological Survey Open-File Report 2003-354, 37 p.

Milici, R.C., and Swezey, C.S., 2006, Assessment of Appalachian Basin oil and gas resources-Devonian Shale-Middle and Upper Paleozoic Total Petroleum Systems: U.S. Geological Survey Open-File Report 2006-1237, 65 p. (Also available at http://pubs.usgs.gov/of/2006/1237/.)

Schmoker, J.W., 2002, U.S. Geological Survey assessment concepts for continuous petroleum accumulations, chap 13 of Petroleum systems and geologic assessment of the southwestern Wyoming province, Wyoming, Colorado, and Utah: U.S. Geological Survey Digital Data Series DDS-69-D. (Also available at http://pubs.usgs.gov/dds/dds069/dds-069-d/REPORTS/69_D_CH_13.pdf.) 


\section{Figures}

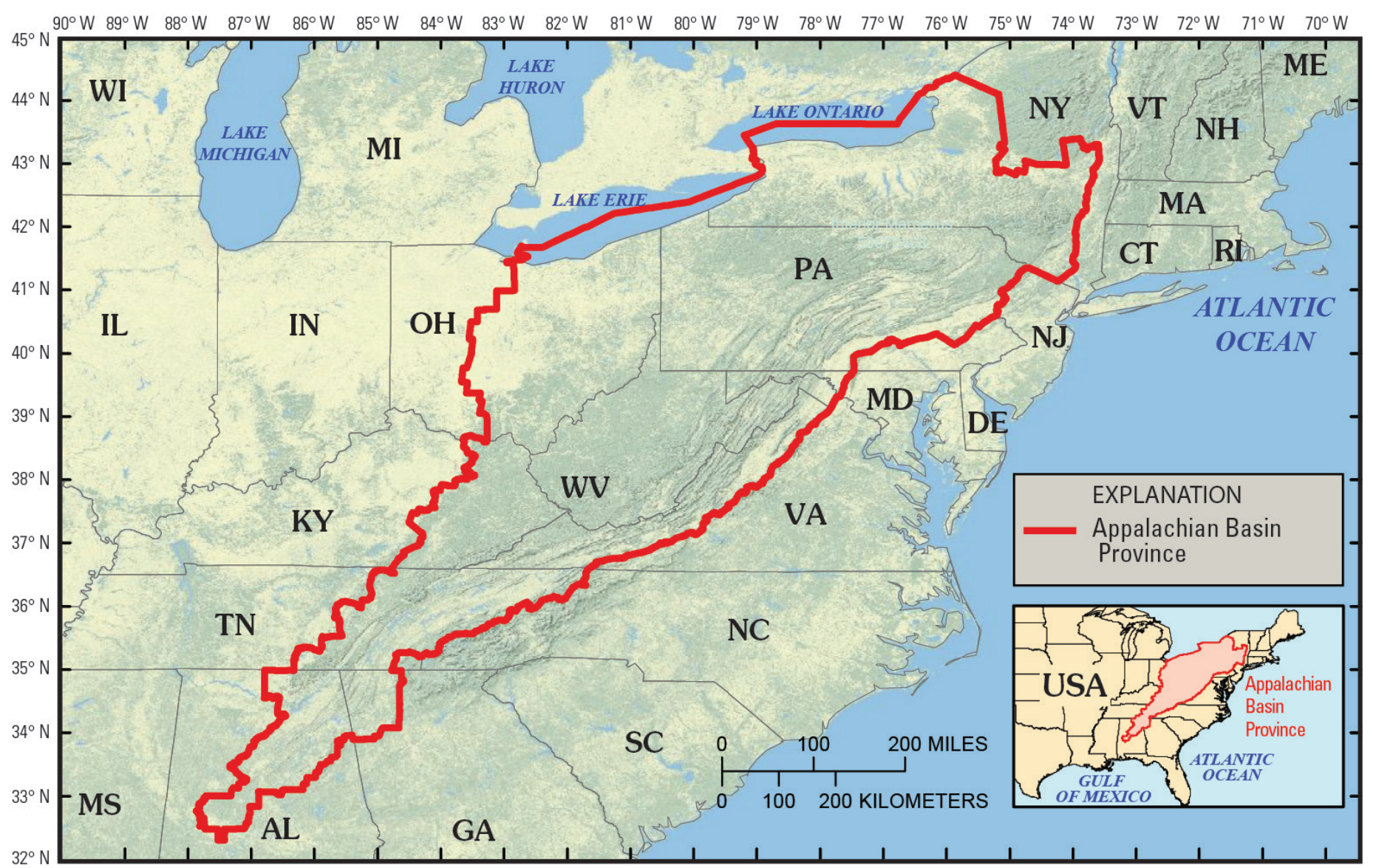

Figure 1. Location map showing the boundary of the Appalachian Basin Province (red line) as defined for USGS assessments. 


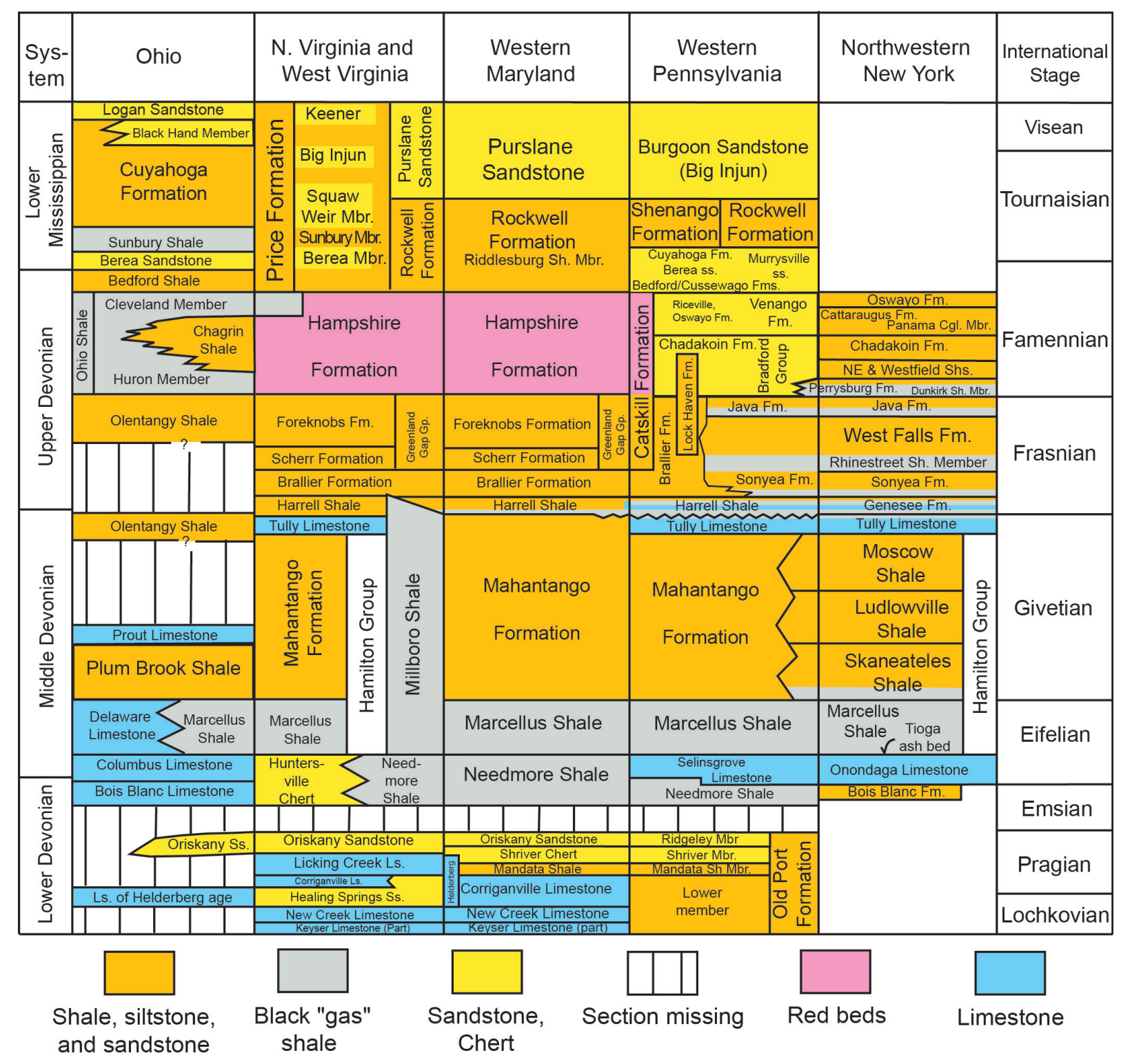

Figure 2. Generalized stratigraphic nomenclature representing late Mississippian and Devonian rocks of the northern part of the Appalachian Basin Province. The Marcellus Shale is Middle Devonian in age. Modified from Milici and Swezey (2006) 


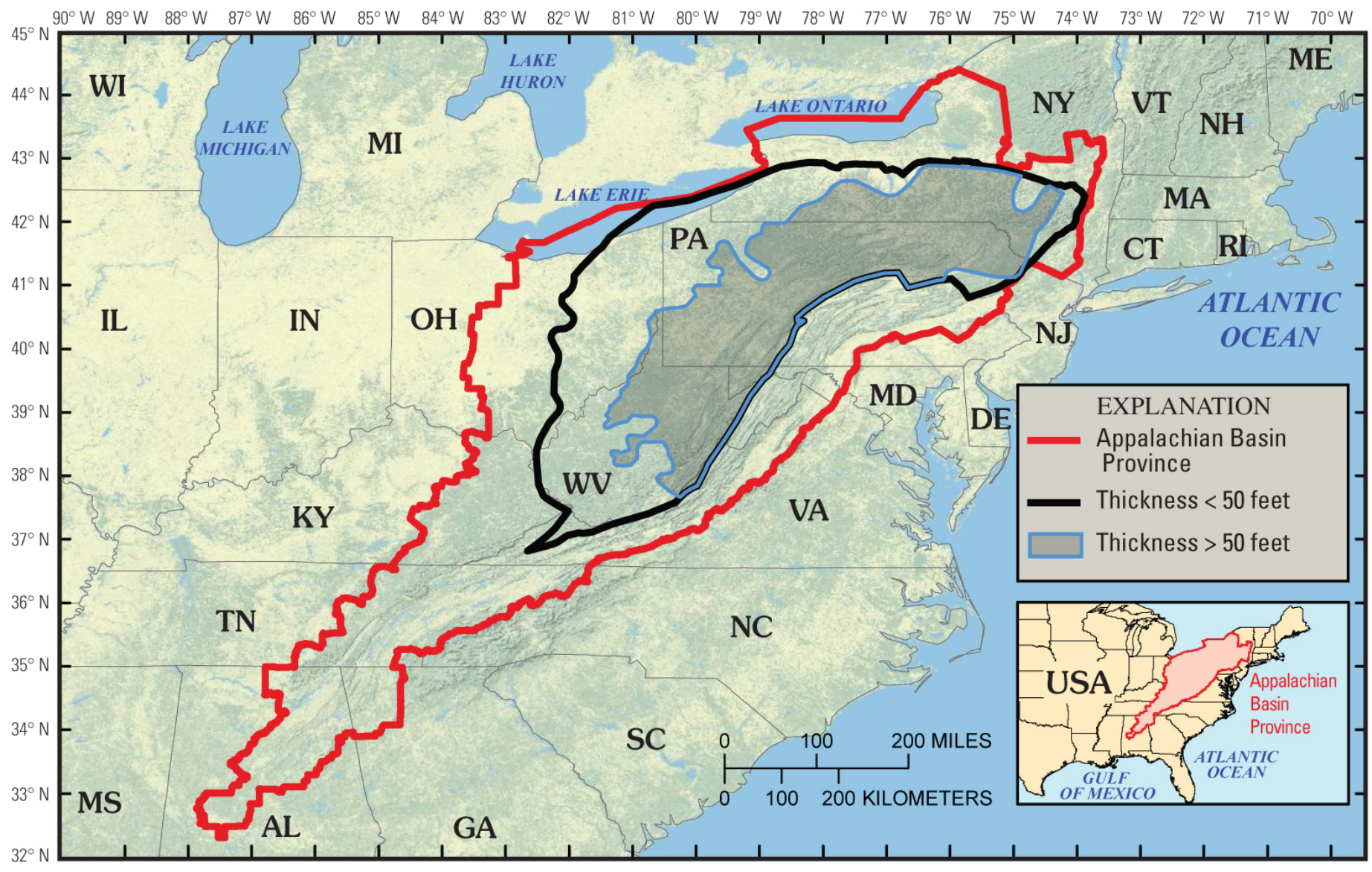

Figure 3. Generalized 50-foot isopach maps of the Marcellus Shale in the Appalachian Basin Province. The shaded area represents the area in which the thickness of the Marcellus Shale is greater than or equal to 50 feet; the unshaded area within the black line represents that area in which the Marcellus Shale is less than 50 feet thick. These isopach lines were used directly in the definition of assessment unit boundaries. 


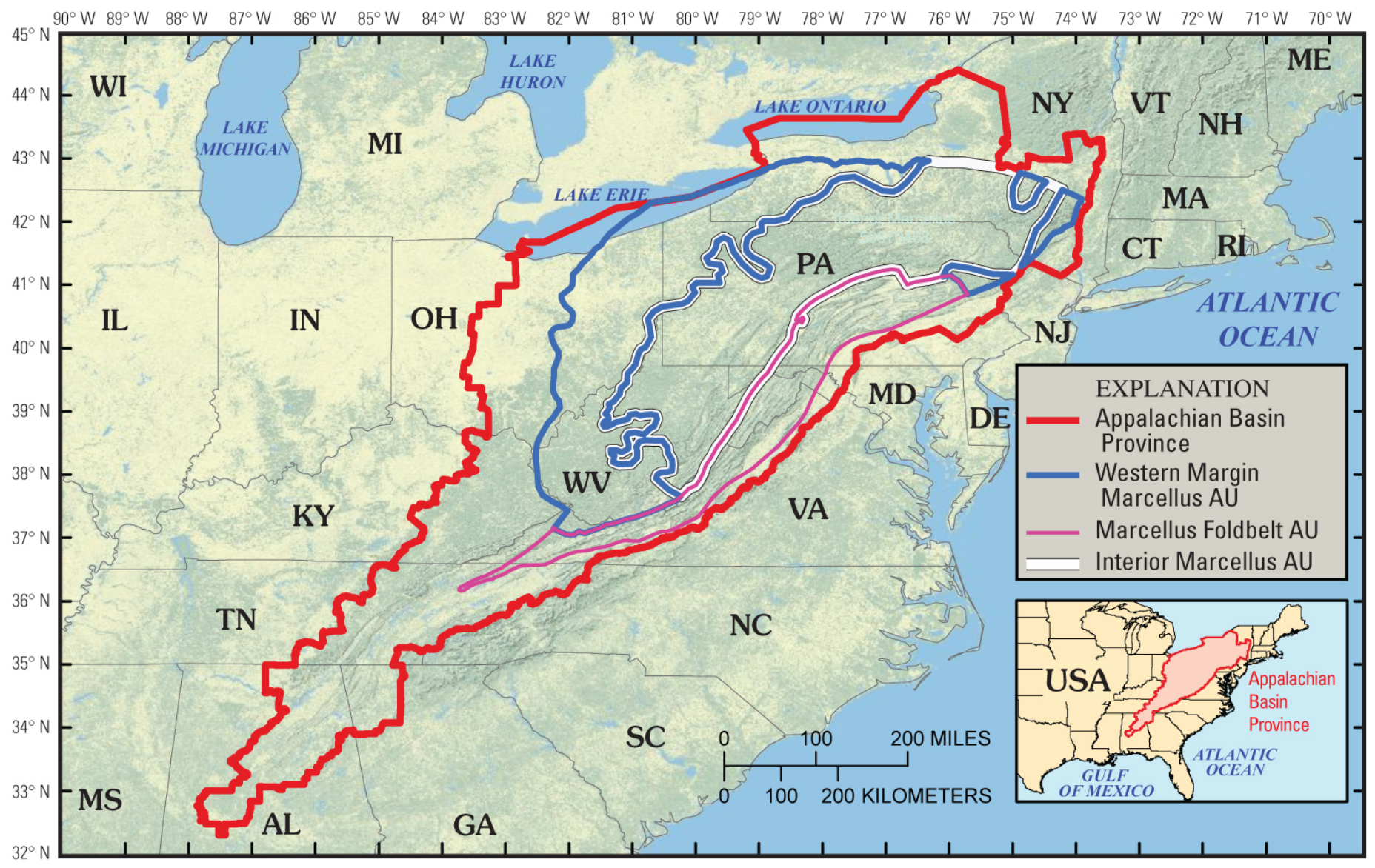

Figure 4. Map showing the boundaries of the three assessment units (AU) of the Marcellus Shale assessed by the USGS. 


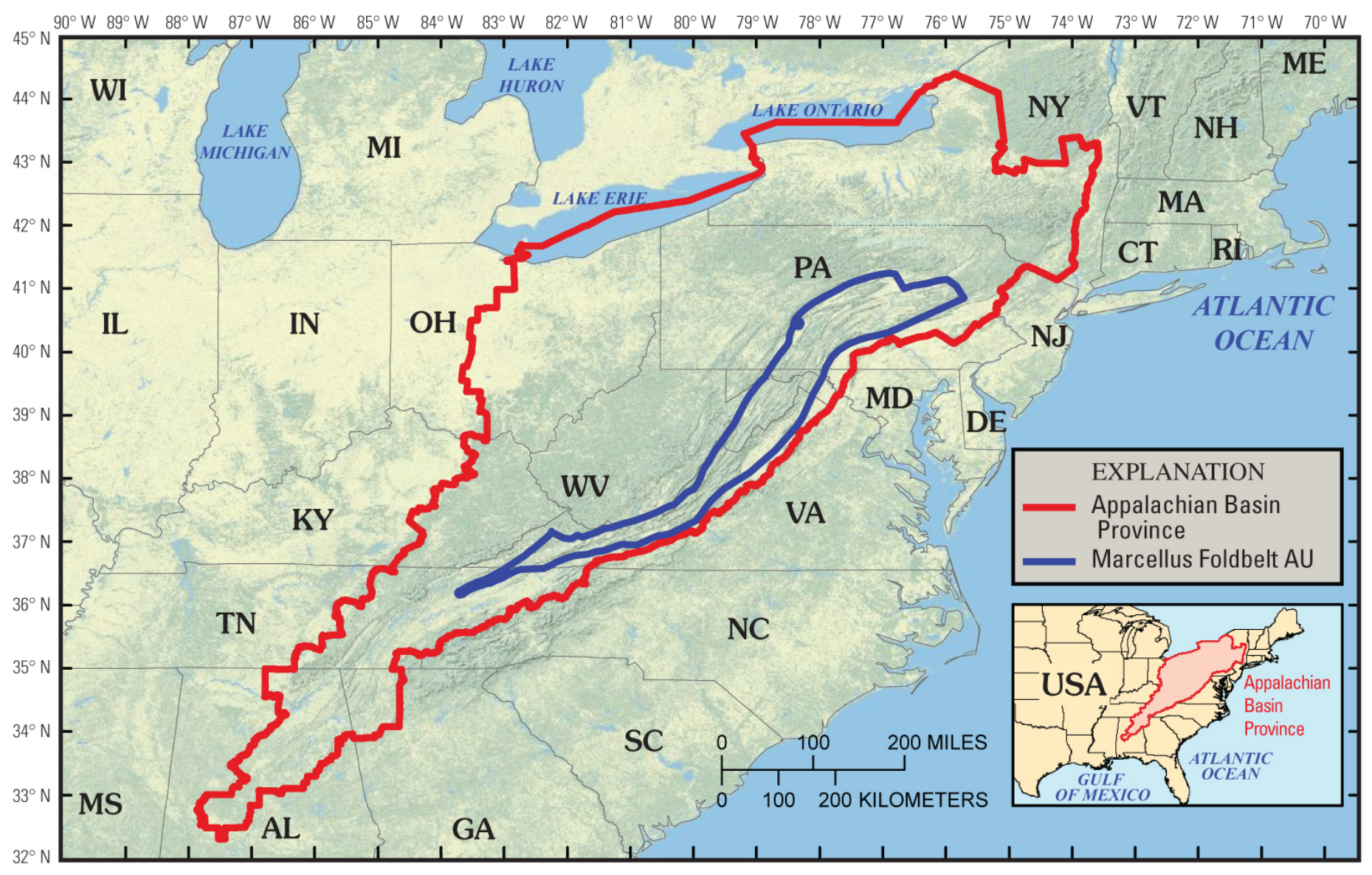

Figure 5. Map showing the boundary of the Foldbelt Marcellus Assessment Unit (AU) in the Appalachian Basin Province. 


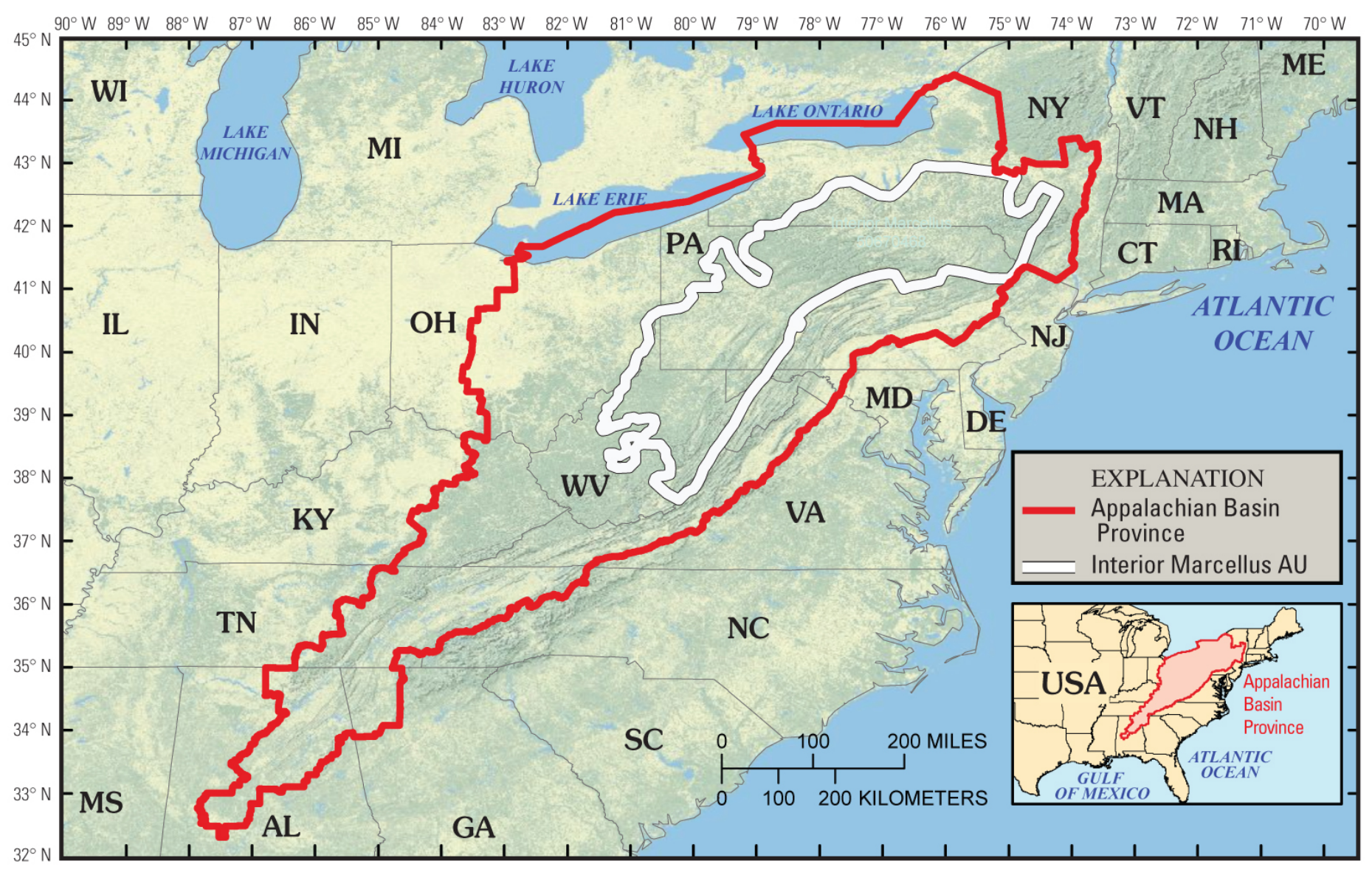

Figure 6. Map showing the boundary of the Interior Marcellus Assessment Unit (AU) in the Appalachian Basin Province. 


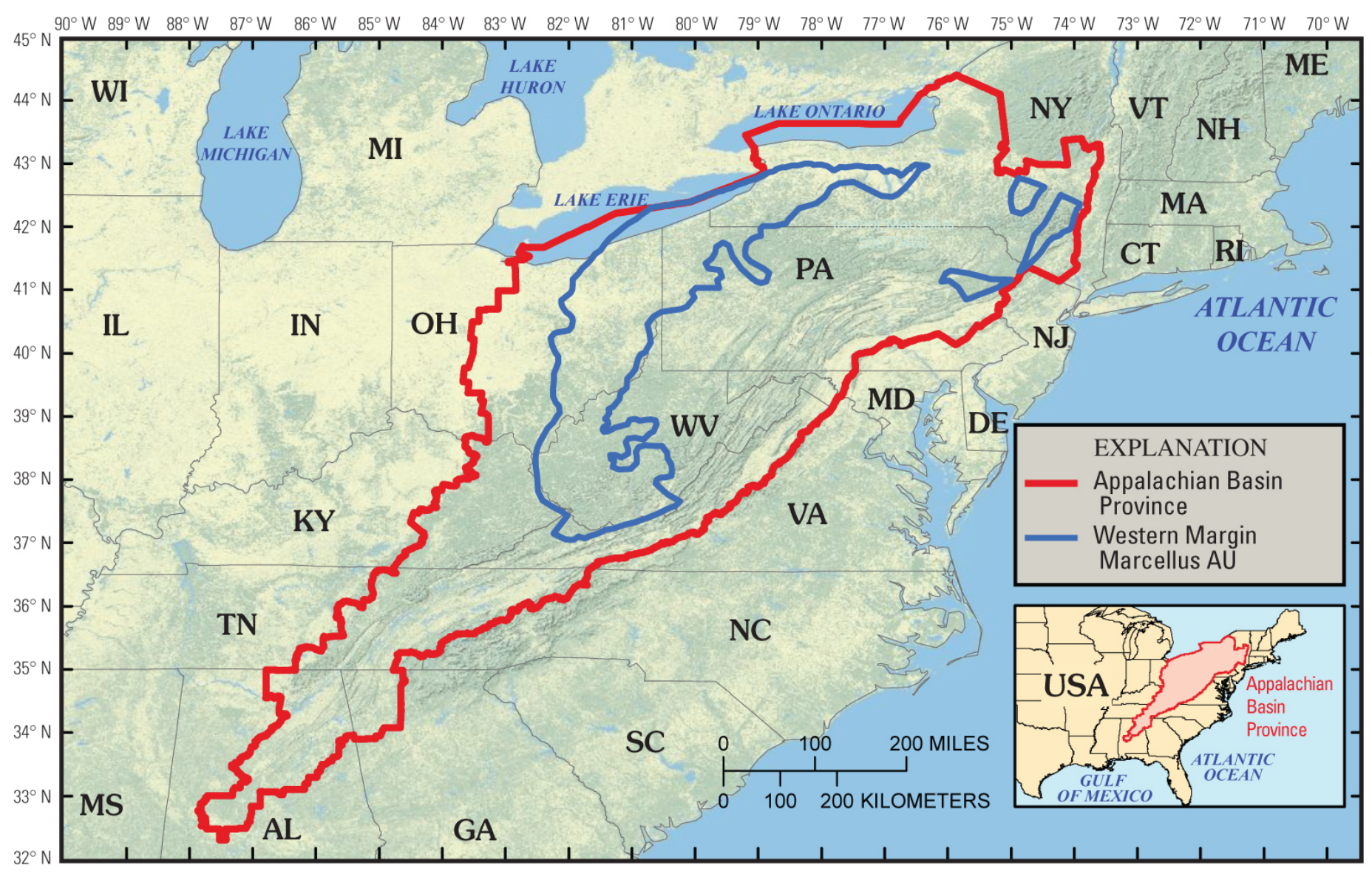

Figure 7. Map showing the boundary of the Western Margin Marcellus Assessment Unit (AU) in the Appalachian Basin Province. 


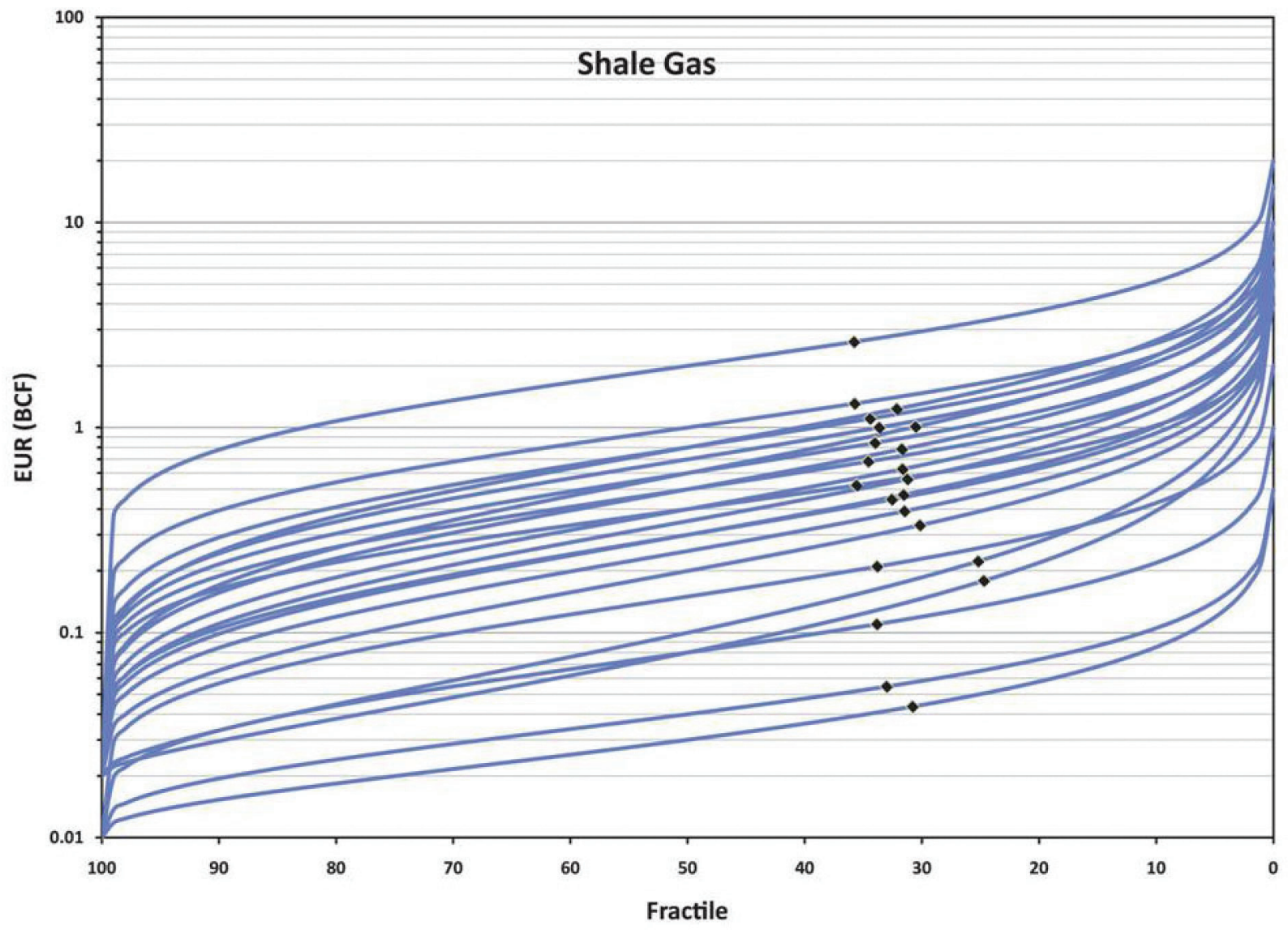

Figure 8. Distributions of Estimated Ultimate Recovery (EUR) for 26 shale gas assessment units assessed by the USGS. Each distribution is a truncated shifted lognormal and represents a smooth curve. Black diamonds represent the mean for each distribution. This family of distributions was used as potential EUR analogs for the three Marcellus Shale assessment units. 
Appendix 1. Geologic input data for the assessment of the Foldbelt Marcellus Assessment Unit (50670467).

Appendix 2. Geologic input data for the assessment of the Interior Marcellus Assessment Unit (50670468).

Appendix 3. Geologic input data for the assessment of the Western Margin Marcellus Assessment Unit (50670469). 